\title{
Hexavalent Chromium Removal by a Paecilomyces sp Fungal
}

\author{
Juan F. Cárdenas-González and Ismael Acosta-Rodríguez \\ Universidad Autónoma de San Luis Potosí, Facultad de Ciencias Químicas, \\ Centro de Investigación y de Estudios de Posgrado, Laboratorio de Micología Experimental \\ S.L.P. México
}

\section{Introduction}

The strong impact of hexavalent chromium on the environment and on the human health demand suitable technologies to neutralize the hazard of chromium. The traditional technologies used for the remediation of environment contaminated with $\mathrm{Cr}$ (VI) are based on physical and chemical approaches, which require large amounts of chemical substances and energy. Such methodologies have proved complete expensive on a large-scale application at contaminated sites, and also they have generated hazardous by-products (Cervantes et. al., 2001). Bioremediation, a strategy that uses living microorganisms, is essentially proposed to clean up the environment from organic pollutants. However, since there is an evidence that several microorganisms possess the capability to reduce $\mathrm{Cr}$ (VI) to relatively toxic $\mathrm{Cr}$ (III), bioremediation gives immense opportunities for the development of technologies for the detoxification of soil contaminated with $\mathrm{Cr}$ (VI) as an alternative to existing physical-chemical remediation technologies (Cervantes et al., 2001).

Chromium is an essential micro-nutrient in the diet of animals and humans, as it is indispensable for the normal sugar, lipid and protein metabolism of mammals. Its deficiency in the diet causes alteration in lipid and glucose metabolism in animals and humans. Chromium is included in the complex named glucose tolerance factor (GFC) (Armienta-Hernández and Rodríguez-Castillo, 1995). On the other hand, no positive effects of chromium are known in plants and microorganisms. However, elevated levels of chromium are always toxic, although the toxicity level is related to the chromium oxidation state. $\mathrm{Cr}$ (VI) not only is highly toxic to all forms of living organisms. It is mutagenic for bacteria, mutagenic and carcinogenic for humans and animals, but also, it is involved in causing birth defects and the decrease of reproductive health (Marsh and McInerney, 2001). This metal may cause death in animals and humans, if ingested in large doses. The LD 50 for oral toxicity in rats is from 50 to $100 \mathrm{mg} / \mathrm{kg}$ for Cr (VI) and $1900-3000 \mathrm{mg} / \mathrm{kg}$ for Cr (III). Cr (VI) toxicity is related to its easy diffusion across the cell membrane in prokaryotic and eukaryotic organisms and subsequent $\mathrm{Cr}(\mathrm{VI})$ reduction in cells, which gives free radicals that, may directly cause DNA alterations as well as toxic effects. $\mathrm{Cr}$ (III) has been estimated to be from 10 to 100 times less toxic than $\mathrm{Cr}$ (VI), because cellular membranes appear to be quite impermeable to most $\mathrm{Cr}$ (III) complexes. Nevertheless, intracellular Cr (III), which is the terminal product of the $\mathrm{Cr}(\mathrm{VI})$-reduction, forms amino acid nucleotide complexes in vivo, whose mutagenic potentiality is not fully known (Gutiérrez Corona, et al., 2010). 
It is well known that prokaryotes are more resistant to $\mathrm{Cr}$ (VI) than eukaryotes. Toxic chromium effects on bacteria, algae and plants have been reviewed by Wong and Trevors (1988). On the contrary, scant information is available about the impact of the chromium on the structure and diversity of soil microbial communities. In many studies, it has been difficult to assess the toxicity of chromium to soil microorganisms, because the environments examined were often polluted at the same time with organic pollutants and/or different heavy metals. In a soil chronically polluted with chromium (about 5000 $\mathrm{mg} / \mathrm{kg}$ of soil) by leather tannery activity, the oxygenic phototrophic microorganisms and heterotrophic bacterial communities were both affected by chromium. Nitrogen-fixing cyanobacteria were not detected in contaminated soil with $\mathrm{Cr}$ using the MPN test, and data obtained from enriched cultures for nitrogen-fixing cyanobacteria showed that this, belonging to the Nostoc group was present, but they had a low number of heterocyst. The size of the cultivable heterotrophic bacterial community was not affected by chromium pollution, but there was a relationship between the percentage of chromate-tolerant bacteria and the level of chromium in the soil (Anjana et al., 2007). The ability of some microorganisms for interact with different $\mathrm{Cr}$ forms makes them attractive in the context of environmental biotechnology. In this sense, the use of microbial biomass for the removal of $\mathrm{Cr}$ from industrial wastewater and polluted water has already been recognized. The properties of some microorganisms for both: tolerate and reduce $\mathrm{Cr}$ (VI) enable their application in biotechnological process focusing on detoxification of $\mathrm{Cr}$ (VI). Cr resistance has been described in bacteria and fungi isolated from Cr-polluted environments. Yeast strains isolated include Candida and Rhodosporidium genera, but in these, the general mechanism of chromate resistance is related to limited ion uptake, rather than to chemical reduction of the toxic species (Baldi, e. al., 1990; Pepi and Baldi, 1992). However, other yeasts such as Candida utilis (Muter, et al., 2001) and Candida maltose (Ramírez-Ramírez, et al., 2004), showed partial ability to reduce $\mathrm{Cr}$ (VI) and also the capability to accumulate $\mathrm{Cr}$ in the biomass. Recent reports have also examined $\mathrm{Cr}$ (III) and $\mathrm{Cr}$ (VI) uptake and accumulation by different filamentous fungi (Acevedo-Aguilar, et al., 2008; Fukuda, et al., 2008; Srivastava and Thakur, 2007; Morales-Barrera and Cristiani-Urbina, 2008). The present study report the isolation and identification of a Paecilomyces sp fungal strain that exhibits high resistance level, resistance, biosorption and reduction potential to $\mathrm{Cr}(\mathrm{VI})$.

\section{Materials and methods}

\subsection{Microorganism and chromate resistance test}

A chromate-resistant filamentous fungus was isolated from polluted air with industrial vapors, in Petri dishes containing modified Lee's minimal medium (LMM, Lee, et al., 1975) [with $0.25 \% \quad \mathrm{KH}_{2} \mathrm{PO}_{4}, \quad 0.20 \% \quad \mathrm{MgSO}_{4}, 0.50 \% \quad\left(\mathrm{NH}_{4}\right)_{2} \mathrm{SO}_{4}, 0.50 \% \quad \mathrm{NaCl}, 0.25 \%$ glucose] supplemented with $500 \mathrm{mg} / \mathrm{L} \mathrm{K}_{2} \mathrm{Cr}_{2} \mathrm{O}_{7}$; the $\mathrm{pH}$ of the medium was adjusted and maintained at 5.3 with $100 \mathrm{mMol} / \mathrm{L}$ citrate-phosphate buffer. The cultures were incubated at $28^{\circ} \mathrm{C}$ for 7 days. The strain was identified based on their morphological structures such color, diameter of the mycelia, and microscopic observation of formation of spores (Kirk, et al., 2001). Chromate-resistant tests of the isolated strain, filamentous fungus Paecilomyces sp, were performed on liquid LMM containing the appropriate nutritional requirements and different concentrations of $\mathrm{Cr}$ (VI) (as potassium dichromate), and determining the dry weight. The isolation was carried out near of Chemical Science Faculty, located in the city of San Luis Potosí, Mexico. 


\subsection{Preparation of biosorbent}

The biomass was obtained by growth the fungus in thioglycollate broth $(8 \mathrm{~g} / \mathrm{L})$ at $28^{\circ} \mathrm{C}$ with constant shaking $(100 \mathrm{rpm})$. After of 4 days of incubation, the fungal biomass was obtained by filtration on Whatman filter paper No. 1. Later, the fungal biomass was centrifuged ( $3000 \mathrm{rpm}, 5 \mathrm{~min})$, washed 3 times with trideionized water, dried $\left(80^{\circ} \mathrm{C}, 12 \mathrm{~h}\right)$ in bacteriological stove, ground in mortar and stored in amber glass bottles at room environment until use.

\subsection{Preparation of stock solution}

An aqueous stock solution (1000 mg/L) of $\mathrm{Cr}(\mathrm{VI})$ ions was prepared using $\mathrm{K}_{2} \mathrm{Cr}_{2} \mathrm{O}_{7}$ salt. $\mathrm{pH}$ of the solution was adjusted using $0.1 \mathrm{~N} \mathrm{HCl}$ or $\mathrm{NaOH}$. Fresh dilutions were used for each study.

\subsection{Biosorption studies}

The biosorption capacity of fungal biomass was determined by contacting various concentrations (100 - $1000 \mathrm{mg} / \mathrm{L})$ of $100 \mathrm{~mL} \mathrm{Cr}$ (VI) solution in $250 \mathrm{ml}$ Erlenmeyer glass flasks, with $1 \mathrm{~g}$ of biomass. The mixture was shaken in a rotary shaker at $120 \mathrm{rpm}$ followed by filtration using Whatman filter paper No. 1. The filtrate containing the residual concentration of $\mathrm{Cr}$ (VI) was determined spectrophotometrically at $540 \mathrm{~nm}$ after complexation with 1, 5 Diphenylcarbazide (Eaton et. al.,1995), Cr (III) with Chromazurol S (Pantaler and Pulyaeva,1985) and Cr total by total by Electrothermal Atomic Absorption Spectroscopy (Eaton et. al.,1995). For the determination of rate of metal biosorption by biomass from $100 \mathrm{~mL}$ (at 200, 400, 600, 800 and 1000, mg/L), the supernatant was analyzed for residual $\mathrm{Cr}(\mathrm{VI})$ after the contact period of 1-12 hours. The effect of $\mathrm{pH}$ and temperature on $\mathrm{Cr}$ (VI) sorption by fungal biomass, was determined at $\mathrm{pH}$ values of $1,2,3$, and $4,28^{\circ} \mathrm{C}$, $40^{\circ} \mathrm{C}, 50^{\circ} \mathrm{C}$ and $60^{\circ} \mathrm{C}$, respectively. The effect of different doses of biomass ranging from 1 to $5 \mathrm{~g} / \mathrm{L}$, with $100 \mathrm{mg} / \mathrm{L}$ of $\mathrm{Cr}(\mathrm{VI})$ concentrations was determined.

\subsection{Culture conditions in liquid media}

Cultures in $100 \mathrm{~mL}$ of sterile LMM [amended with $50 \mathrm{mg} / \mathrm{L} \mathrm{Cr}$ (VI)] inoculated with $5 \times 10^{5}$ spores $/ \mathrm{mL}$ were incubated at $28^{\circ} \mathrm{C}$ for $48 \mathrm{~h}$. Then, cells were aseptically separated by centrifugation at 2,000 rpm $\left(4^{\circ} \mathrm{C}\right)$ for $10 \mathrm{~min}$, and washed twice with sterile trideionized water to eliminate culture medium components and cell debris. The cell pellet was resuspended in $3 \mathrm{~mL}$ of sterile trideionized water by shaking in a vortex mixer for 30s, and was then transferred to $100 \mathrm{~mL}$ of fresh LMM amended with $50 \mathrm{mg} / \mathrm{L} \mathrm{Cr}$ (VI). At various times during the course of incubation, $1 \mathrm{~mL}$ aliquots were removed and centrifuged at 5,000 rpm for $10 \mathrm{~min}$ to sediment the cells; the supernatant fluid was used to determine the concentration of hexavalent, trivalent or total Cr.

\subsection{Determination of hexavalent, trivalent, and total $\mathrm{Cr}$}

Hexavalent $\mathrm{Cr}$ and trivalent $\mathrm{Cr}$ were quantified by a spectrophotometric method employing diphenylcarbazide and chromazurol S, respectively (Eaton et al., 1995; Pantaler and Pulyaeva, 1985), total Cr was determined by electrothermal atomic absorption spectroscopy (Eaton et al., 1995).

The values shown in the results section are the mean from three experiments carried out by triplicate. 


\subsection{Bioremediation assay}

Two $250 \mathrm{ml}$ Erlenmeyer glass flasks, with $5 \mathrm{~g}$ of fungal biomass, were add with $20 \mathrm{~g}$ of contaminated earth with $50 \mathrm{mg} \mathrm{Cr}(\mathrm{VI}) / \mathrm{g}$ earth of tannery (Celaya , Guanajuato, México), and the volume was complete to $100 \mathrm{~mL}$ with trideionized water. The mixture was shaken in a rotary shaker at $120 \mathrm{rpm}$ followed by filtration using Whatman filter paper No1. The filtrate containing the residual concentration of $\mathrm{Cr}$ (VI) was determined with 1, 5 diphenylcarbazide (Eaton et al., 1995).

\section{Results and discussion}

\subsection{Isolation and identification of a fungal strain capable of removing $\mathbf{C r}$ (VI)}

The fungal strain isolated was able to growth on LMM supplemented with $2000 \mathrm{mg} / \mathrm{L}$ of $\mathrm{Cr}$ (VI) (Figure 1). This indicates that this fungus developed the Cr (VI) resistance and probably the $\mathrm{Cr}(\mathrm{VI})$ is being reduced in the polluted air. A variety of microorganisms with the $\mathrm{Cr}(\mathrm{VI})$ resistance and $\mathrm{Cr}$ (VI) reducing ability have been isolated from effluents of tanneries (Seng and Wang, 1994; Dark, et al., 2004; Fukuda, et.al., 2008). Colonies of the isolated fungal strain grew rapidly and mature within 3 days. Paecilomyces sp are thermopile and can grow well at temperatures as high as $50^{\circ}$ and $60^{\circ} \mathrm{C}$. The colonies are flat, powdery or velvety in texture. The initial color is white, and becomes yellow, yellow-green, pink, or violet. The reverse is dirty white or buff. A sweet aromatic color may be associated with older cultures. Septate hyaline hyphae, conidiophores, phialides, conidia, and chlamidospores are observed. Conidiophores (3-4 $\mu \mathrm{m}$ wide and 400-600 $\mu \mathrm{m}$ long) are often branched and carry the phialides at their tips. The phialides are swollen at their bases and taper towards their apices. They are usually grouped in pair or brush-like clusters. Conidia are unicellular, hyaline to darkly colored, smooth or rough, oval to fusoid, and form long chains. Chlamidospores are occasionally present. With different concentrations of $\mathrm{Cr}$ (VI) include changes in morphologies, showing slower growth and least conidiation (Figure 2) (Kirk, et al., 2001).

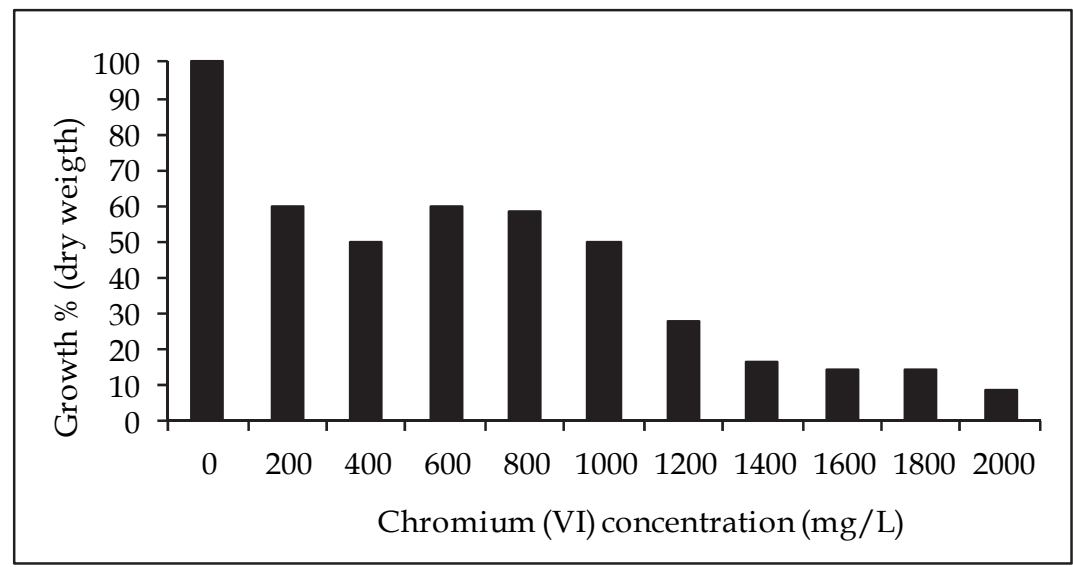

Fig. 1. Growth in dry weight of Paecilomyces sp with different concentrations of $\mathrm{Cr}$ (VI). $1 \times 10^{5}$ spores $/ \mathrm{mL}, 28^{\circ} \mathrm{C}, 7$ days of incubation, $100 \mathrm{rpm}$. 

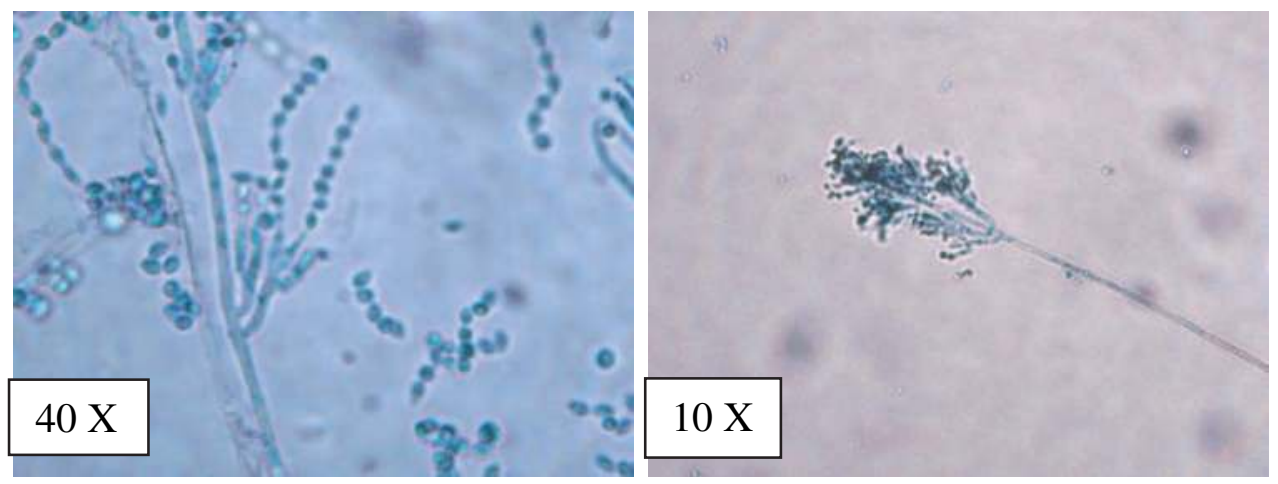

Fig. 2. Microscopic morphology of the fungus Paecilomyces sp. In absence and presence of $500 \mathrm{mg} / \mathrm{L}$ of $\mathrm{Cr}(\mathrm{VI})$, respectively.

\subsection{Studies with fungal biomass}

\subsubsection{Effect of $\mathrm{pH}$ and incubation time}

Figure 3 shows the adsorption of $\mathrm{Cr}(\mathrm{VI})$ by $1.0 \mathrm{~g} / 100 \mathrm{~mL}$ of fungal biomass as a function of time at $\mathrm{pH}$ of 1.0, 2.0, 3.0 and 4.0, for initial $\mathrm{Cr}(\mathrm{VI})$ concentration of $100 \mathrm{mg} / \mathrm{L}$. The metal removal was found to be $100 \%$ at 9 hours and $79.2 \%$ at 10 hours, with $\mathrm{pH} 1.0$ and 2.0, respectively. Aqueous phase $\mathrm{pH}$ governs the speciation of metals and also the dissociation of active functional sites on the sorbent. Hence, metal sorption is critically linked with $\mathrm{pH}$.

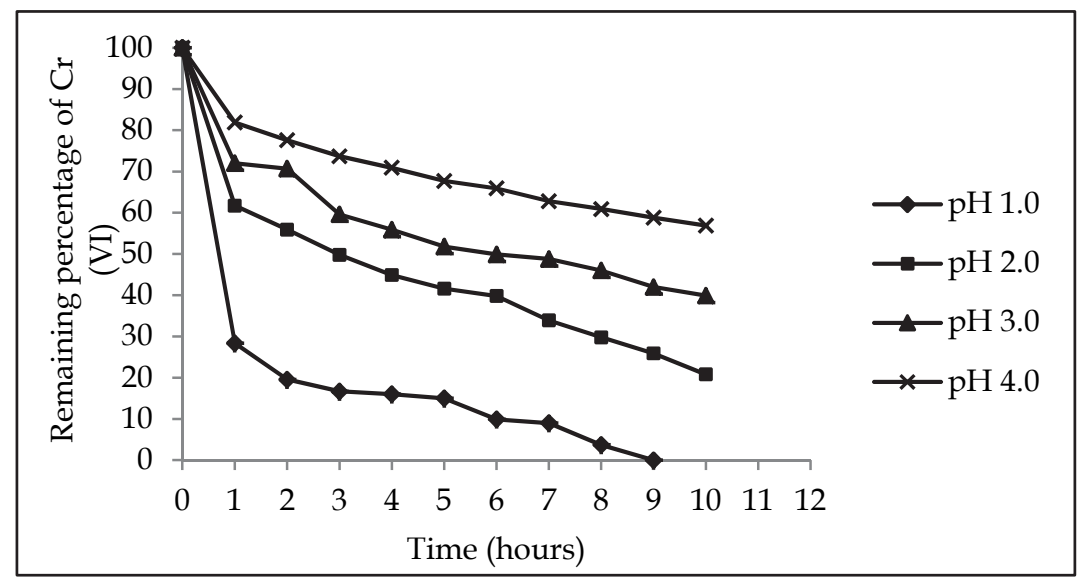

Fig. 3. Effect of $\mathrm{pH}$ and incubation time on the removal of $100 \mathrm{mg} / \mathrm{L} \mathrm{Cr}(\mathrm{VI}) .28^{\circ} \mathrm{C} .1 \mathrm{~g}$ of fungal biomass. $100 \mathrm{rpm}$.

Not only different metals show different $\mathrm{pH}$ optima for their sorption but may also vary from one kind of biomass to the other (Tewari et al., 1995; Ucun et al., 2002). It can be observed from the figure that the uptake of $\mathrm{Cr}$ (VI) decreases with increase in $\mathrm{pH}$. In general, the $\mathrm{Cr}$ (VI) adsorption by different biosorbents have shown similar trend and the optimum pH 1.0 has been reported (Nourbakhsh et.al., 1994). The literature has reported an optimal $\mathrm{pH}$ for the 
removal of Cr (VI) by the fungi Rhizopus arrhizus and Saccharomyces cerevisiae in a range of 1.52.5, at $4 \mathrm{~h}$ (Nourbakhsh et al., 1994), although most show a $\mathrm{pH}$ optimum of removal in the range of 2.0 to 3.0 (Tewari et al., 2005; with Mucor hiemalis; Sag and Aktay, 2002, for Rhizopus arrhizus, both at $24 \mathrm{~h}$, Bai and Abraham, 2001; with Rhizopus nigricans, at $8 \mathrm{~h}$ ). The highest sorption capacity of mandarin shell for Chromium (VI) was at $\mathrm{pH} 1.0$ and the decrease in sorption capacity with increase in $\mathrm{pH}$ may be attributed to the changes in metal speciation and the dissociation of functional groups on the sorbent. Ucun et al., (2002) have reported that the $\mathrm{pH}$ dependence of metal uptake could be largely related to the various functional groups on the adsorbent surface along with metal solution chemistry.

\subsubsection{Effect of temperature}

Temperature dependence of the adsorption process is associated with several thermodynamic parameters. Figure 4 shows an increasing trend of $\mathrm{Cr}$ (VI) removal with the rise in temperature from 28 to $60^{\circ} \mathrm{C}$. Results that is consistent with those of Park et al., (2004), who observed that at $45^{\circ} \mathrm{C}$ and $24 \mathrm{~h}$, adsorption occurs for the same metal with Aspergillus niger, and Leyva-Ramos et al., (2005) for the removal of cadmium (II) with corn cob $\left(40{ }^{\circ} \mathrm{C}\right.$ and 5 days), but differ from $35^{\circ} \mathrm{C}$ and $24 \mathrm{~h}$ reported by Sag and Aktay (2002) for Rhizopus arrhizus, and with those reported for mandarin flax husk (Zubair, et al., 2008). The increase in Cr (VI) uptake may be due to creation of some new sorption sites on the sorbent surface or the increased rate of intraparticle diffusion of sorbate ions into the pores of adsorbent at higher temperature, as diffusion is an endothermic process (Das, et al., 2000).

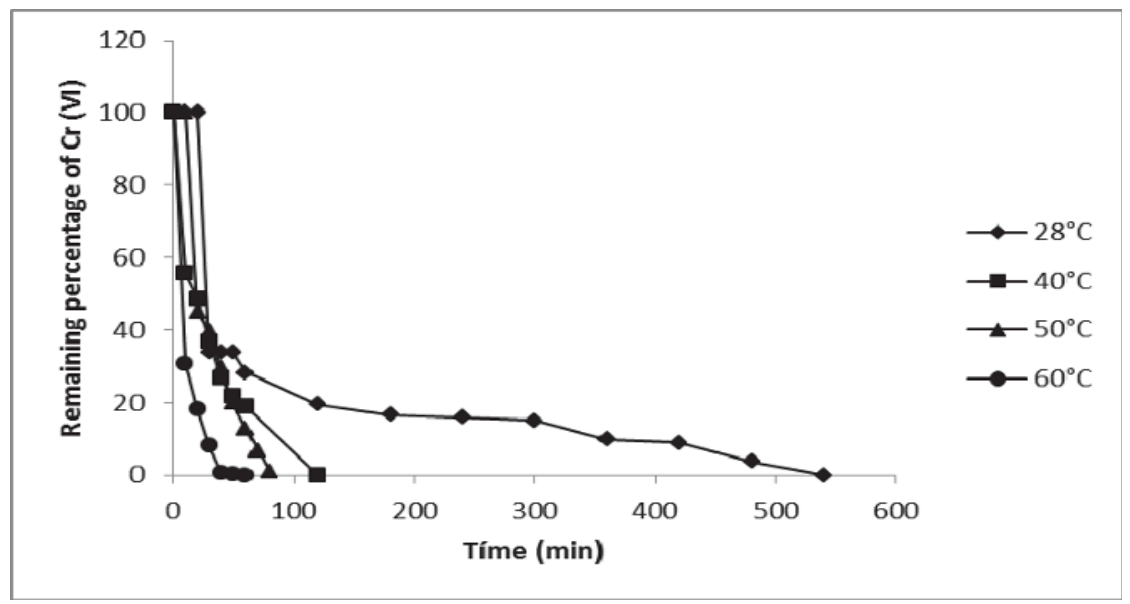

Fig. 4. Effect of temperature on the removal of $100 \mathrm{mg} / \mathrm{L} \mathrm{Cr}$ (VI). $1 \mathrm{~g}$ of fungal biomass. $100 \mathrm{rpm}$

\subsubsection{Effect of $\mathrm{Cr}(\mathrm{VI})$ concentration}

The time taken to remove $200 \mathrm{mg} / \mathrm{L}$ chromium solution was $70 \mathrm{~min}$. But as the chromium concentration increased, the percentage of chromium biosorption progressively decreased from $100 \%$ in $100 \mathrm{mg} / \mathrm{L}$ to $80 \%$ in $1000 \mathrm{mg} / \mathrm{L}$ solution, to $60^{\circ} \mathrm{C}$ (Figure 5a), and to $28^{\circ} \mathrm{C}, 200$ and $1000 \mathrm{mg} / \mathrm{L}$ of the metal was remove in 9 and 12 hours, respectively (Figure 5b). This appears to be due to the increase in the number of ions competing for the available binding 
sites in the biomass and also due to the lack of binding sites for the complexation of $\mathrm{Cr}$ ions at higher concentration levels. At lower concentrations, all metal ions present in the solution would interact with the binding sites and thus facilitated $100 \%$ adsorption. At higher concentrations, more $\mathrm{Cr}$ ions are left unabsorbed in solution due to the saturation of binding sites (Ahalya et al. 2005).

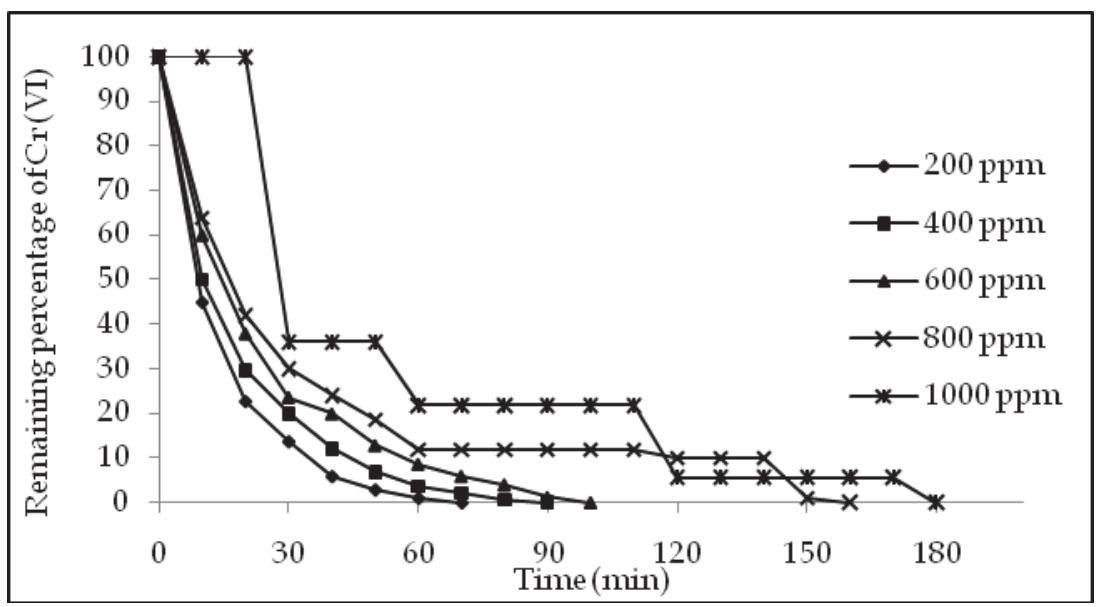

(a)

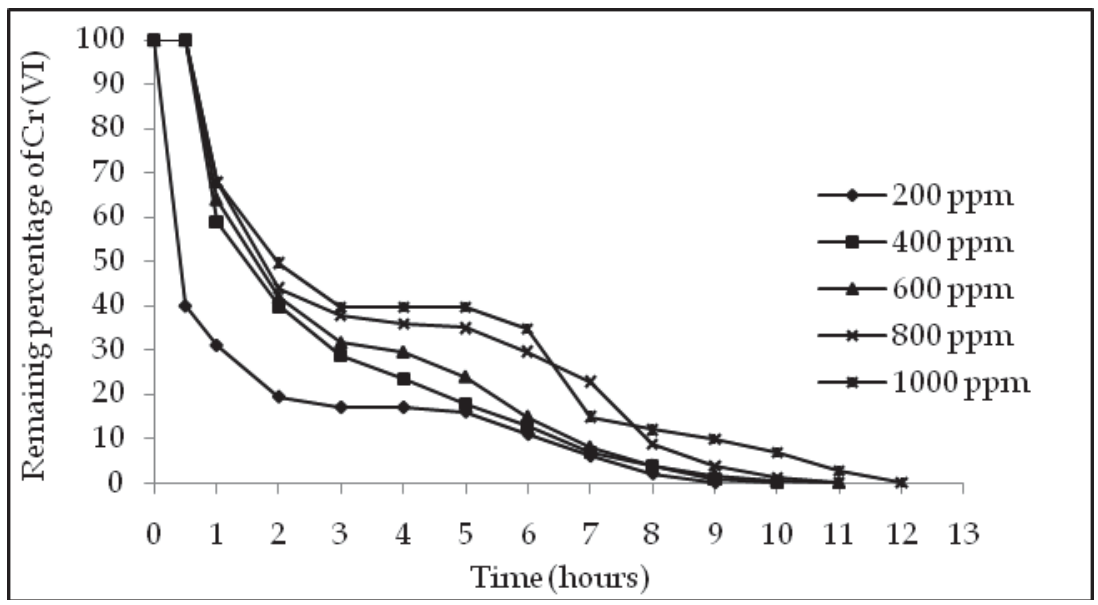

(b)

Fig. 5. Effect of $\mathrm{Cr}(\mathrm{VI})$ concentration on the removal of the metal. $1 \mathrm{~g}$ of fungal biomass. 100 rpm. a. $-60^{\circ} \mathrm{C}$. b. $-28^{\circ} \mathrm{C}$.

\subsubsection{Effect of biomass concentration}

We studied the removal of $1000 \mathrm{mg} / \mathrm{L}$ of $\mathrm{Cr}$ (VI) with various concentrations of fungal biomass at $60^{\circ} \mathrm{C}$, finding that to higher concentration of biomass, is better the biosorption of $\mathrm{Cr}(\mathrm{VI})$, because the metal is removed at 70 minutes using $5.0 \mathrm{~g}$ of biomass (Figure 6). If we 
increasing the amount of biomass, also increases the removal of $\mathrm{Cr}$ (VI) in solution, since there are more metal biosorption sites, because the amount of added biosorbent determines the number of binding sites available for metal biosorption (Cervantes et al., 2001). Similar results have been reported for biomass Mucor hiemalis and Rhizopus nigricans, although the latter with $10 \mathrm{~g}$ of biomass (Tewari et al., 2005, Bai and Abraham, 2001), but are different from those reported by Zubair et al., (2008), for mandarin flax husk biomass, who report an optimal concentration of biomass of $100 \mathrm{mg} / \mathrm{L}$.

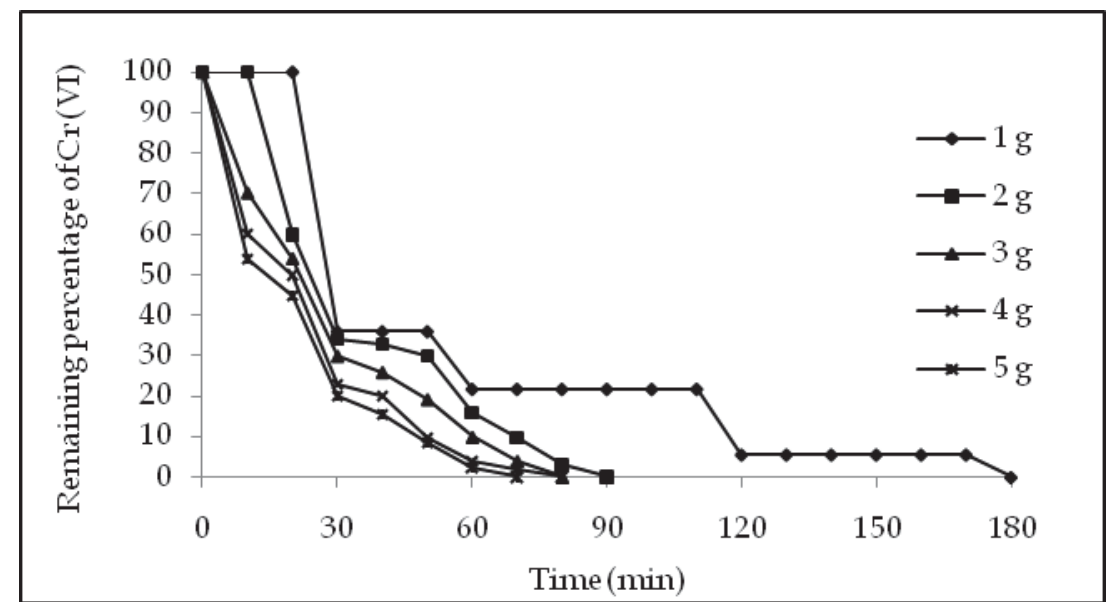

Fig. 6. Effect of biomass concentration on the removal of $1.0 \mathrm{~g} / \mathrm{L}$ of $\mathrm{Cr}(\mathrm{VI}) .100 \mathrm{rpm} .60^{\circ} \mathrm{C}$.

Finally, Table 1 shows the adsorption efficiency of $\mathrm{Cr}$ (VI) by different biomass of microorganisms which shows that the biomass of Paecilomyces sp reported in this study is the most efficient in the removal of metal.

\subsection{Studies with fungal alive 3.3.1 Effect of $\mathrm{pH}$}

Figure 7 shows the effect of varying $\mathrm{pH}(4.0,5.3$, and 7.0, maintained with $100 \mathrm{mMol} / \mathrm{L}$ citrate-phosphate buffer.) on the rate of $\mathrm{Cr}$ (VI) removal. The rate of chromium uptake and the extent of that capture were enhanced as the $\mathrm{pH}$ falls from 7.0 to 4.0. The maximum uptake was observed at $\mathrm{pH} 4.0$ (96\% at 7 days), 96\%, Liu et. al., (2007) and Bai and Abraham, (2001) reported maximum removal at $100 \mathrm{mg} / \mathrm{L} \mathrm{Cr}$ (VI) solution using Mucor racemosus and Rhizopus nigricans with $\mathrm{pH}$ optimum of $0.5-1.0$, and 2.0 respectively, Sandana Mala et.al., (2006) at pH 5.0 for Cr (VI) with Aspergillus niger MTCC 2594, Rodríguez et. al., (2008) at pH 3.0-5.0 for $\mathrm{Pb}^{+2}, \mathrm{Cd}^{+2}$ and $\mathrm{Cr}^{+3}$ with the yeast Saccharomyces cerevisiae, Park et. al., (2004) at $\mathrm{pH}$ 1-5 for Cr (VI) with brown seaweed Ecklonia, Higuera et. al., (2005) at pH 5.0 for Cr (VI) with the brown algae Sargassum sp, and Fukuda et. al., (2008) at pH 3.0 for $\mathrm{Cr}$ (VI) with Penicillium sp. In contrast to our observations, Prasenjit and Sumathi (2005), reported maximum uptake of $\mathrm{Cr}$ (VI) at $\mathrm{pH} 7.0$ with Aspergillus foetidus, Puranik and Paknikar (1985) reported an enhanced uptake of lead, cadmium, and zinc, with a shift in $\mathrm{pH}$ from 2.0 to 7.0 using a Citrobacter strain, and a decrease at higher $\mathrm{pH}$ values. Al-Asheh and Duvnjak (1995) also demonstrated a positive effect of increasing $\mathrm{pH}$ in the range 4.0-7.0 on $\mathrm{Cr}$ (III) uptake using Aspergillus carbonarius. At low $\mathrm{pH}$, the negligible removal of chromium may be due to the 
competition between hydrogen $(\mathrm{H}+)$, and metal ions Srivasta and Thakur (2007). At higher $\mathrm{pH}(7.0)$, the increased metal removal may be due to the ionization of functional groups and the increase in the negative charge density on the cell surface. At alkaline $\mathrm{pH}$ values $(8.0$ or higher), a reduction in the solubility of metals may contribute to lower uptake rates.

\begin{tabular}{|c|c|c|}
\hline Biosorbent & $\begin{array}{c}\text { Capacity of adsorption } \\
(\mathrm{mg} / \mathrm{g})\end{array}$ & References \\
\hline Aspergillus foetidus & 2 & Prasenjit and Sumathi (2005) \\
\hline Aspergillus niger & 117.33 & Khambhaty et al. (2009) \\
\hline Aspergillus sydowi & 1.76 & Kumar et al. (2008) \\
\hline Rhizopus nigricans & 47 & Bai and Abraham (2001) \\
\hline Rhizopus oligosporus & 126 & Ariff et al. (1999) \\
\hline Rhizopus arrhizus & 11 & Bai and Abraham (1998) \\
\hline Rhizopus arrhizus & 78 & Aksu and Balibek (2007) \\
\hline Rhizopus sp. & 4.33 & Zafar et al. (2007) \\
\hline Mucor hiemalis & 53.5 & Tewari et al. (2005) \\
\hline Paecilomyces $s p$ & 1000 & (Present study) \\
\hline Bacillus coagulans & 39.9 & Srinath et al. (2002) \\
\hline Bacillus megaterium & 30.7 & Srinath et al. (2002) \\
\hline Zoogloea ramigera & 2 & Nourbakhsh et al. (1994) \\
\hline Streptomyces noursei & 1.2 & Mattuschka and Straube (1993) \\
\hline Chlorella vulgaris & 3.5 & Nourbakhsh et al. (1994) \\
\hline Cladophora crispate & 3 & Nourbakhsh et al. (1994) \\
\hline Dunaliella $s p$. & 58.3 & Donmez and Aksu (2002) \\
\hline Pachymeniopis sp. & 225 & Lee et al. (2000) \\
\hline
\end{tabular}

Table 1. Capacity of biosorption of different microbial biomass for removal $\mathrm{Cr}$ (VI) in aqueous solution.

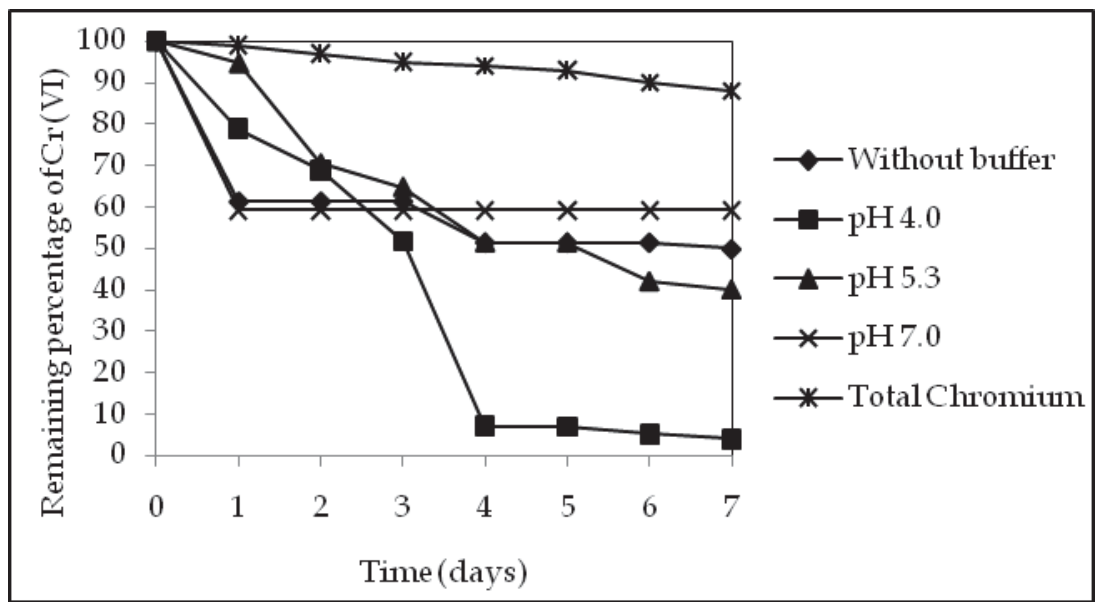

Fig. 7. The effect of $\mathrm{pH}$ on Chromium (VI) removal by Paecilomyces sp. $50 \mathrm{mg} / \mathrm{L} \mathrm{Cr}$ (VI), $100 \mathrm{rpm}, 28^{\circ} \mathrm{C}$. 


\subsubsection{Effect of cell concentration}

The influence biomass in the removal capacity of $\mathrm{Cr}(\mathrm{VI})$ was depicted in Figure 8. From the analyzed (38, 76, and $114 \mathrm{mg}$ of dry weight) the removal capacity was in the order of $99.17 \%$, $97.95 \%$, and $97.25 \%$, respectively. In contrast to our observations, the most of the reports in the literature observe at higher biomass dose resulted in an increase in the percentage removal [1,3, 7, 8, 19, and 22]. To higher biomass concentration, there are more binding sites for complex of $\mathrm{Cr}$ (VI) (e.g. $\mathrm{HCrO}^{-4}$ and $\mathrm{Cr}_{2} \mathrm{O} 7^{-2}$ ions) (Seng and Wang, 1994; Cervantes et. al., 2001). However it did not show in our observations.

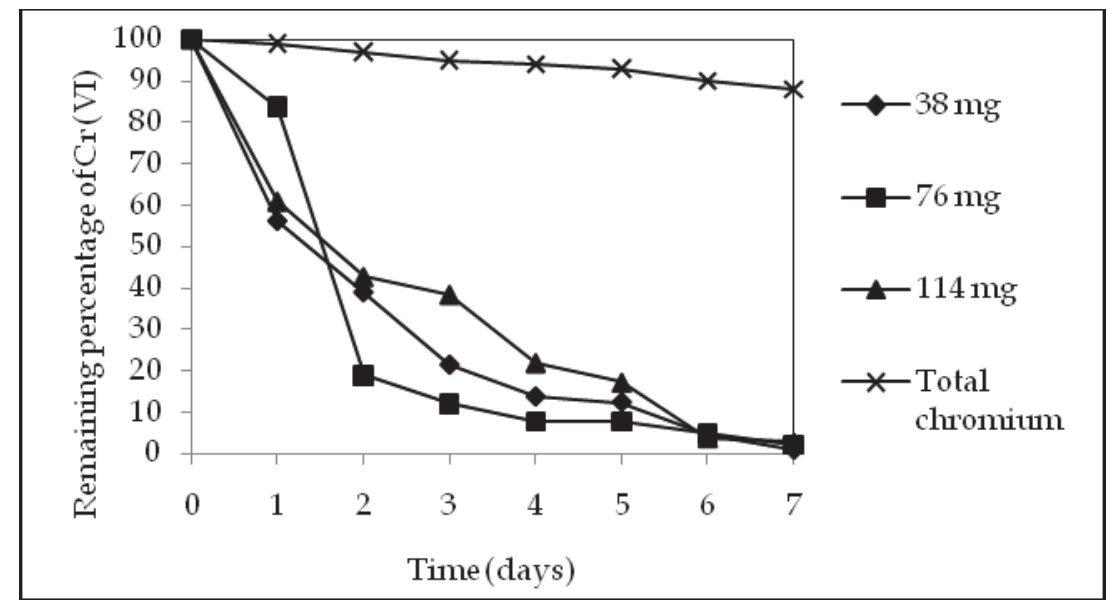

Fig. 8. The effect of cell concentration on the removal of $50 \mathrm{mg} / \mathrm{L} \mathrm{Cr}(\mathrm{VI}), 100 \mathrm{rpm}, 28^{\circ} \mathrm{C}, \mathrm{pH}$ 1.0 .

\subsubsection{Effect of initial $\mathrm{Cr}(\mathrm{VI})$ concentration}

As seen in Figure 9, when the initial Cr (VI) ions concentration increased from $50 \mathrm{mg} / \mathrm{L}$ to $200 \mathrm{mg} / \mathrm{L}$, the percentage removal of metal ions decreased. This was due to the increase in the number of ions competing for the available functions groups on the surface of biomass. Our observations are like to the most of the reports in the literature (Bai and Abraham, 2001; Seng and Wang, 1994; Beszedits, 1988; Park et. al., 2004; Sahin and A. Öztürk, 2005; Liu, et. al., 2007; Rodríguez, et. al., 2008; Park et. al., 2004; Higuera Cobos et. al., 2005).

\subsubsection{Effect of carbon source}

Figures 10a and 10b, shows that the decrease of $\mathrm{Cr}$ (VI) level in culture medium of Paecilomyces sp occurred exclusively in the presence of a carbon source, either fermentable (glucose, sucrose, fructose, citrate) or oxidable (glycerol). In the presence of glucose, other inexpensive commercial carbon sources like unrefined sugar and brown sugar or glycerol, the decrease in $\mathrm{Cr}(\mathrm{VI})$ levels occurred at a similar rate, at 7 days of incubation are of $99.17 \%$, $100 \%, 94.28 \%, 81.5$, and $99 \%$, respectively, and the other carbon sugar were fewer effectives. On the other hand, incubation of the biomass in the absence of a carbon source did not produce any noticeable change in the initial $\mathrm{Cr}(\mathrm{VI})$ concentration in the growth medium. These observations indicated that in culture of the fungus a carbon source is required to provide the reducing power needed to decrease $\mathrm{Cr}(\mathrm{VI})$ in the growth medium. Our 
observations are like to the report of Acevedo-Aguilar, et. al., (2008) and Prasenjit and Sumathi (2005), with glucose like carbon source, and are different to the observations of Srivasta and Thakur (2007) with Aspergillus sp and Acinetobater sp, who observed how the main carbon source the sodium acetate.



Fig. 9. The effect of the concentration of $\mathrm{Cr}(\mathrm{VI})$ in solution on the removal, $100 \mathrm{rpm} .28^{\circ} \mathrm{C}$, $\mathrm{pH} 4.0$.

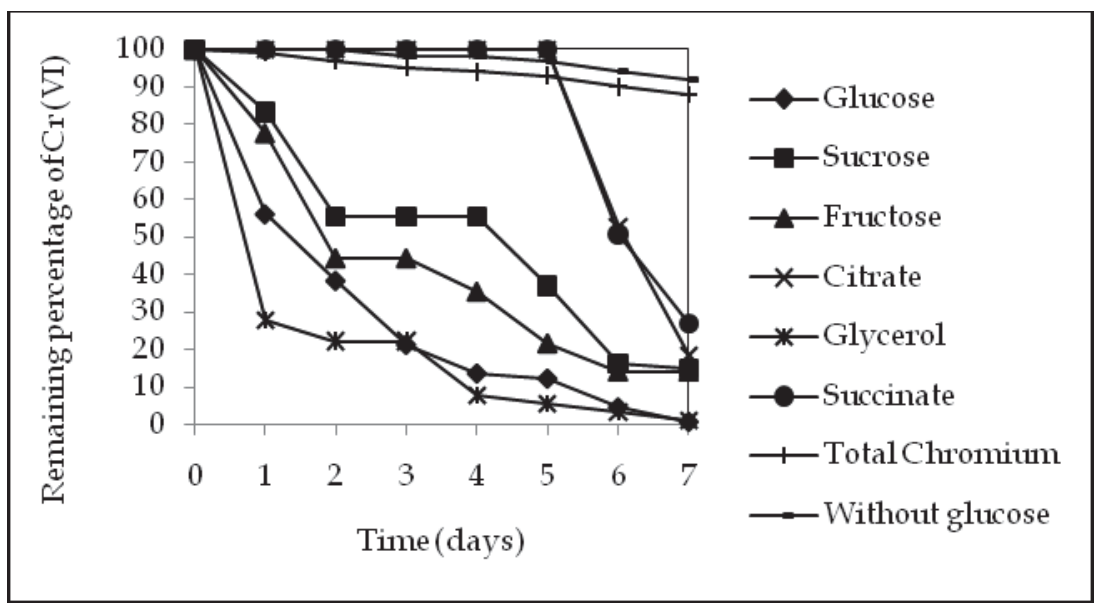

Fig. 10. (a) Influence of carbon source on the capability of Paecilomyces sp to decrease $\mathrm{Cr}$ (VI) levels in the growth medium. $100 \mathrm{rpm}, 28^{\circ} \mathrm{C}, \mathrm{pH} 4.0$ 


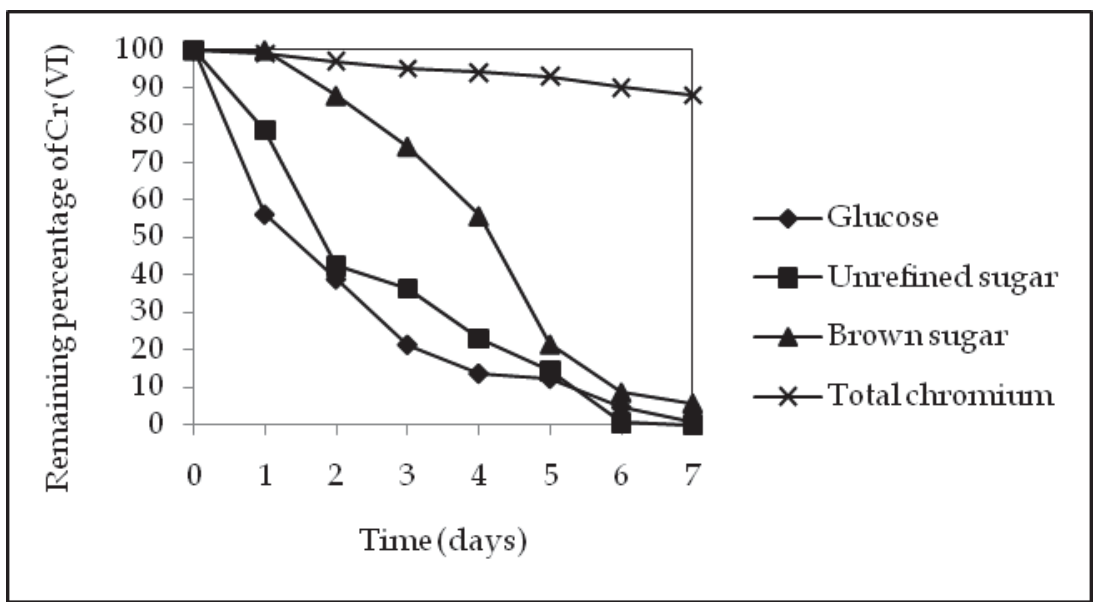

Fig. 10. (b) Influence of commercial carbon sources and salt on the capability of Paecilomyces sp to decrease $\mathrm{Cr}(\mathrm{VI})$ levels in the growth medium. $100 \mathrm{rpm}, 28^{\circ} \mathrm{C}, \mathrm{pH} 4.0$

\subsubsection{Time course of $\mathrm{Cr}(\mathrm{VI})$ decrease and $\mathrm{Cr}$ (III) production}

The ability of the isolated strain to lower the initial $\mathrm{Cr}$ (VI) of $50 \mathrm{mg} / \mathrm{L}$, and Cr (III) production in culture medium was analyzed. Figure 11A show that Paecilomyces $\mathrm{sp}$ exhibited a remarkable efficiency to diminish $\mathrm{Cr}$ (VI) level with the concomitant production of $\mathrm{Cr}$ (III) in the growth medium (indicated by the formation of a blue-green color and a white precipitate, and its determination by Cromazurol S, (Figure No. $11 \mathrm{~B}$ ) (Pantaler and Pulyaeva, 1985). Thus, after 7 days of incubation, the fungus strain caused a drop in $\mathrm{Cr}$ (VI) from its initial concentration of $50 \mathrm{mg} / \mathrm{L}$ to almost undetectable levels. As expected, total $\mathrm{Cr}$ concentration remained constant over time, in medium without inoculum. These observations indicate that Paecilomyces sp strain is able to reduce $\mathrm{Cr}(\mathrm{VI})$ to $\mathrm{Cr}$ (III) in growth medium amended with chromate. There are two mechanisms by which chromate could be reduced to a lower toxic oxidation state by an enzymatic reaction. Currently, we do not know whether the fungal strain used in this study express and $\mathrm{Cr}$ (VI) reducing enzyme(s). Further studies are necessary to extend our understanding of the effects of coexisting ions on the $\mathrm{Cr}$ (VI) reducing activity of the strain reported in this study. Cr (VI) reducing capability has been described in some reports in the literature (Smith et. al., 2002; Sahin and A. Öztürk, 2005; Muter et. al., 2001; Ramírez-Ramírez et. al., 2004; Acevedo-Aguilar, et. al., 2008; Fukuda et. al., 2008). Biosorption is the second mechanism by which the chromate concentration could be reduced, and $1 \mathrm{~g}$ of fungal biomass of Paecilomyces $\mathrm{sp}$ is able to remove $1000 \mathrm{mg} / \mathrm{L}$ of $\mathrm{Cr}$ (VI) at $60^{\circ} \mathrm{C}$, at 3 hours of incubation (Figure 4), because the fungal cell wall can be regarded as a mosaic of different groups that could form coordination complexes with metals, and our observations are like to the most of the reports in the literature (Bai and Abraham, 2001; Seng and Wang, 1994; Ramírez-Ramírez et. al., 2004; Acevedo-Aguilar, et. al., 2008; Fukuda et. al., 2008; Prasenjit and Sumathi, 2005). 

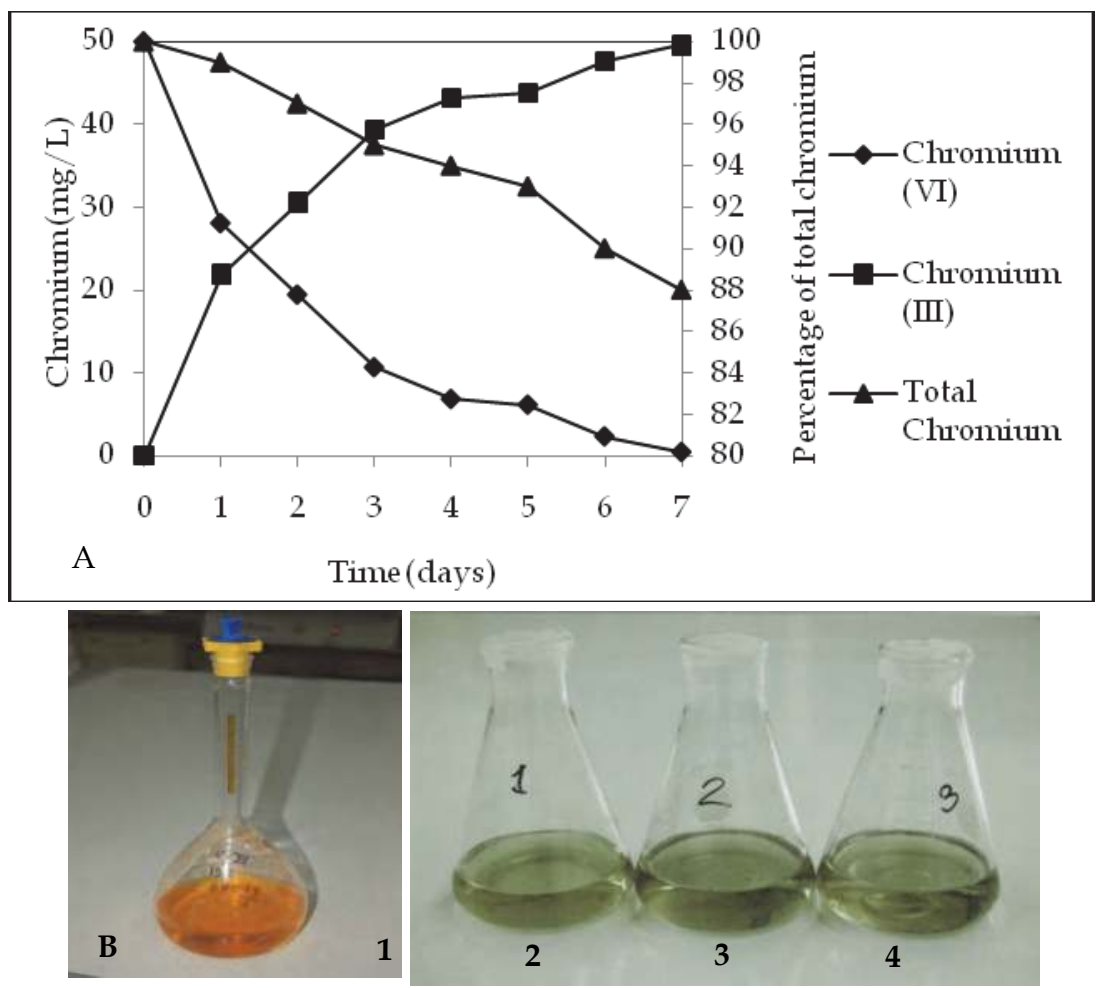

Fig. 11. Time-course of $\mathrm{Cr}$ (VI) decrease and $\mathrm{Cr}$ (III) production in the spent medium of culture initiated in Lee's minimal medium, amended with $50 \mathrm{mg} / \mathrm{L} \mathrm{Cr}(\mathrm{VI}), 100 \mathrm{rpm}, 28^{\circ} \mathrm{C}$, $\mathrm{pH} 4.0$ (A). B. - Appearance of the solutions. Total $\mathrm{Cr}$ coupled with the biomass, after different incubation times in the presence of $\mathrm{Cr}(\mathrm{VI})$. 1. - Standard solutions of $\mathrm{Cr}(\mathrm{VI})$ (1.0 g/L, pH=1.0). 2.-25 mg/L 3.-50 mg/L 4.-100 mg/L

\subsubsection{Removal of $\mathrm{Cr}(\mathrm{VI})$ in industrial wastes with fungal biomass}

We adapted a water-phase bioremediation assay to explore possible usefulness of strain of Paecilomyces sp, for eliminating Cr (VI) from industrial wastes, the mycelium biomass was incubated with non sterilized contaminated soil containing $50 \mathrm{mg} \mathrm{Cr}(\mathrm{VI}) / \mathrm{g}$, suspended in LMM, pH 4.0. It was observed that after eight days of incubation with the Paecilomyces $\mathrm{sp}$ biomass, the $\mathrm{Cr}$ (VI) concentration of soil sample decrease fully (Figure 12), and the decrease level occurred without change significant in total $\mathrm{Cr}$ content, during the experiments. In the experiment carried out in the absence of the fungal strain, the $\mathrm{Cr}(\mathrm{VI})$ concentration of the soil samples decreased by about of $18 \%$ (date not shown); this might be caused by indigenous microflora and (or) reducing components present in the soil. The chromium removal abilities of Paecilomyces sp are equal or better than those of other reported strains, for example Candida maltose RR1 (Ramírez-Ramírez et. al., 2004). In particular, this strain was superior to the other strains because it has the capacity for efficient chromium reduction under acidic conditions. Most other $\mathrm{Cr}$ (VI) reduction studies were carried out at neutral $\mathrm{pH}$ (Fukuda et. al., 2008; Greenberg et. al., 1992). Aspergillus niger also has the ability to reduce 
and adsorb Cr (VI) (Fukuda et. al., 2008). When the initial concentration of Cr (VI) was 500 ppm, A. niger mycelium removed $8.9 \mathrm{mg}$ of chromium/g dry weight of mycelium in 7 days. In the present study, Paecilomyces sp, remove $50 \mathrm{mg} / \mathrm{g}$, (pH, 4.0 and 8 days).

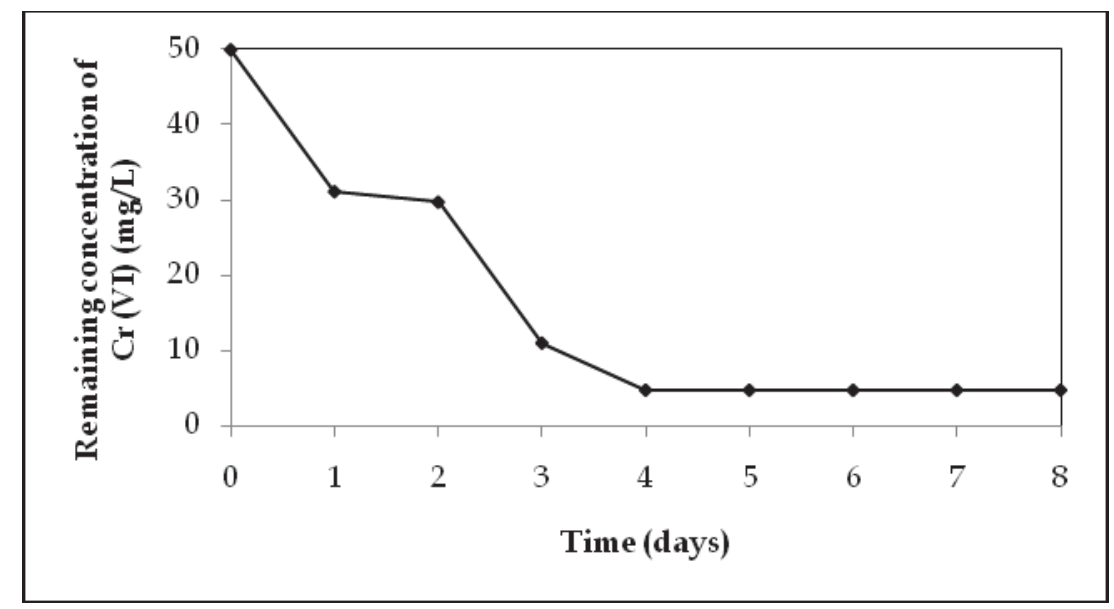

Fig. 12. Removal of Chromium (VI) in industrial wastes incubated with the fungal biomass. $100 \mathrm{rpm}, 28^{\circ} \mathrm{C}, \mathrm{pH} 4.0,50 \mathrm{~g}$ of contaminated soil (50 mg Cr (VI)/g soil).

Reports on applications of microorganisms for studies of bioremediation of soils contaminated with chromates are rare. One such study involved the use of unidentified bacteria native to the contaminated site, which are used in bioreactors to treat soil contaminated with $\mathrm{Cr}$ (VI). It was found that the maximum reduction of $\mathrm{Cr}$ (VI) occurred with the use of $15 \mathrm{mg}$ of bacterial biomass per $\mathrm{g}$ of soil (wet weight), $50 \mathrm{mg}$ per $\mathrm{g}$ of soil molasses as carbon source, the bioreactor operated under these conditions, completely reduced $5.6 \mathrm{mg} / \mathrm{Cr}$ (VI) per $\mathrm{g}$ of soil at 20 days (Jeyasingh and Philip, 2004). In another study using unidentified native bacteria-reducing $\mathrm{Cr}$ (VI) of a contaminated site, combined with Ganoderma lucidum, the latter used to remove by biosorption $\mathrm{Cr}$ (III) formed. The results showed that the reduction of $50 \mathrm{mg} / \mathrm{L}$ of $\mathrm{Cr}$ (VI) by bacteria was about $80 \%$, with $10 \mathrm{~g} / \mathrm{L}$ of peptone as a source of electrons and a hydraulic retention time of $8 \mathrm{~h}$. The $\mathrm{Cr}$ (III) produced was removed using a column with the fungus $\mathrm{G}$. lucidum as absorber. Under these conditions, the specific capacity of adsorption of $\mathrm{Cr}$ (III) of $\mathrm{G}$. Lucidum in the column was $576 \mathrm{mg} / \mathrm{g}$ (Krishna and Philip, 2005). In other studies, has been tested the addition of carbon sources in contaminated soil analyzed in column, in one of these studies was found that the addition of tryptone soy to floor to add to with $1000 \mathrm{mg} / \mathrm{L}$ of $\mathrm{Cr}$ (VI) increase reduction ion, due to the action of microorganisms presents in the soil, although such action is not observed in soil with higher concentrations $(10.000 \mathrm{mg} / \mathrm{L})$ of Cr (VI) (Tokunaga et al., 2003). Another study showed that the addition of nitrate and molasses accelerates the reduction of $\mathrm{Cr}$ (VI) to $\mathrm{Cr}$ (III) by a native microbial community in microcosms studied, in batch or in columns of unsaturated flow, under conditions similar to those of the contaminated zone. In the case of batch microcosms, the presence of such nutrients caused reduction of $87 \%(67 \mathrm{mg} / \mathrm{L}$ of initial concentration) of $\mathrm{Cr}(\mathrm{VI})$ present at the start of the experiment, the same nutrients, added to a column of unsaturated flow of $15 \mathrm{~cm}$, added with $65 \mathrm{mg} / \mathrm{L}$ of $\mathrm{Cr}$ (VI) caused the reduction and immobilization of the $10 \%$ of metal, in a period of 45 days (Oliver et al., 2003). 


\section{Conclusion}

A fungal strain resistant to $\mathrm{Cr}$ (VI) and capable of removing the oxyanion from the medium was isolated from the environment near Chemical Science Faculty, located in the city of San Luis Potosí, Mexico. The strain was identified as Paecilomyces sp, by macro and microscopic characteristics. It was concluded that application of this biomass on the removal of $\mathrm{Cr}$ (VI) in aqueous solutions can be used since $1 \mathrm{~g}$ of fungal biomass remove 100 and $1000 \mathrm{mg} / 100 \mathrm{~mL}$ of this metal after one and three hours of incubation, and remove $297 \mathrm{mg} \mathrm{Cr}$ (VI) of waste soil contaminated, and this strain showed the capacity at complete concentrations reduction of $50 \mathrm{mg} / \mathrm{L} \mathrm{Cr}$ (VI) in the growth medium after 7 days of incubation, at $28^{\circ} \mathrm{C}, \mathrm{pH} 4.0,100$ rpm and a inoculum of $38 \mathrm{mg}$ of dry weight. These results suggest the potential applicability of Paecilomyces sp for the remediation of $\mathrm{Cr}(\mathrm{VI})$ from polluted soils in the Fields.

\section{References}

Acevedo-Aguilar, F.A., Wrobel, K. Lokits, K., Caruso, J.A., Coreño Alonso, A., GutiérrezCorona, J.F. \& Wrobel, K. 2008. Analytical speciation of chromium in in-vitro cultures of chromate-resistant filamentous fungi. Analytical Bioanalytical Chemistry, Vol: 392, No. 1-2, (September, 2008), 269-276, ISSN 1618-2642.

Ahalya, N., Kanamadi, R.D. \& Ramachandra, T.V. 2005. Biosorption of chromium (VI) from aqueous solutions by the husk of Bengal gram (Cicer arientinum). Electronic Journal of Biotechnology, Vol: 8, No. 3, (December, 2005), 1-7, ISSN 0717-3458.

Al-Asheh S. \& Duvnjak, Z. 1995. Adsorption of copper and chromium by Aspergillus carbonarius. Biotechnology Progress, Vol: 11, No. 6, (November-December, 1995), 638642, ISSN 1520-6033.

Anjana, K., Kaushik, A., Kiran, B. \& Nisha, R. 2007. Biosorption of Cr (VI) by immobilized biomass of two indigenous strains of cyanobacteria isolated from metal contaminated soil. Journal of Hazardous Materials, Vol: 148, No.1-2, (September, 2007), 383-386, ISSN 0304-3894.

Ariff, A.B., Mel, M., Hasan, M.A., Karim, M.I.A. 1999. The kinetics and mechanism of lead (II) biosorption by powderized Rhizopus olgisporus, World Journal of Microbiology Biotechnology, Vol: 15, No. 2, (April, 1999), 291-298, ISSN 0959-3993.

Aksu, Z. \& Balibek, E. 2007. Chromium (VI) biosorption by dried Rhizopus arrhizus: effect of salt $(\mathrm{NaCl})$ concentration on equilibrium and kinetic parameters. Journal of Hazardous Materials, Vol: 145, No. 2, (January, 2007), 210-220, ISSN 0304-3894.

Armienta-Hernández, M. \& Rodríguez-Castillo, R. 1995. Environmental exposure to Chromium compounds in the valley of León, México. Environmental Health Perspectives, Vol: 103, No. 12, (December, 1995), 47- 51, ISSN 1022222.

Bai, R.S. \& Abraham, T.E. 2001. Biosorption of chromium (VI) from aqueous solution by Rhizopus nigricans. Bioresource Technology, Vol: 79, No. 1, (September, 2001), 73-81, ISSN 09608524.

Baldi, F., Vaughan, A.M. \& Olson, G.J., 1990. Chromium(VI)-resistant yeast isolated from a sewage treatment plant receiving tannery wastes. Applied and Environmental Microbiology, Vol: 56, (February, 1990), 913-918, ISSN 1098-5336.

Beszedits, S. 1988. Chromium removal from industrial wastewaters. In: Chromium in the natural and human environments. J.O. Nriagu and E. Nieboer (Eds.). 232-263, 1988. New York: John Wiley.

Cervantes, C., Campos-García, J., Devars, S., Gutiérrez-Corona, F., Loza-Tavera, H., TorresGúzman, J.C. \& Moreno-Sánchez, R. 2001. Interactions of chromium with 
microorganisms and plants. FEMS Microbiology Review, Vol: 25, No. 3, (July, 2001), 335-347. ISSN 1574-6976.

Das, D.D., Mahapatra, R., Pradhan, J., Das, S.N. \& Thakur, R.S. 2000. Removal of Cr (VI) from aqueous solution using activated cow dung carbon. Journal of Colloids and Interface Science, Vol: 232, No. 2, (December, 2000), 235-240, ISSN 0021-9797.

Donmez, G.C. \& Aksu, Z. 2002. Removal of chromium (VI) from saline wastewaters by Dunaliella species. Process Biochemistry, Vol: 38, No. 4, (December, 2002), 751-762, ISSN 1359-5113.

Eaton, A.D., Clesceri, L.S. \& Greenberg, A.E. 1995. Standard Methods for the Examination of Water and Wastewater, 19th ed. American Public Health Association Washington, DC, 1325, 3.58, 3.60, ISSN 0875530478.

Fukuda, Y., Ishino, A., Ogawa, K., Tsutsumi, X. \& Morita, H. 2008. Cr(VI) reduction from contaminated soils by Aspergillus sp. N2 and Penicillium sp. N3 isolated from chromium deposits. Journal of General and Applied Microbiology, Vol: 54, No. 5, (September, 2008), 295-303, ISSN 1349-8037.

Gadd, G.M. 1989. Accumulation of metals by microorganisms and algae. In: Biotechnology: a comprehensive treatise. Rhem H.J., Reed, G. (eds). VCH, Weinheim, Germany, Vol: 6B, 401-433.

Greenberg, A.E., Clesceri, L.S. \& Eaton, A.D. 1992. Standard methods for the examination of water and wastewater, 18a ed. 58-3.60, 187-190, (1992). American Public Health Association, Washington, D.C. ISSN 0875530478.

Gutiérrez Corona, J.F., Espino Saldaña, A.E., Coreño Alonso, A., Acevedo Aguilar, F.J., Reyna López, G.E., Fernández, F.J., Tomasini, A., Wrobel, K. \& Wrobel, K. 2010. Mecanismos de interacción con cromo y aplicaciones biotecnológicas en hongos. Revista Latinoamericana de Biotecnología Ambiental y Algal, Vol: 1, No. 1, (Mayo, 2010), 47-63 ISSN. En trámite.

Higuera Cobos, O.F., Escalante Hernández, H. \& Laverde, D. 2005. Reducción del cromo contenido en efluentes líquidos de la industria del cuero, mediante un proceso adsorción-desorción con algas marinas. Scientia et Técnica, Año XII, No. 29, (Abril, 2005), 115-120, ISSN 0122-1701.

Jeyasingh, J., \& Philip, L. 2005. Bioremediation of chromium contaminated soil: optimization of operating parameters under laboratory conditions. Journal of Hazardous Materials, Vol: 118 No. 1-3, (January, 2005), 113-120, ISSN 0304-3894.

Khambhaty, Y., Mody, K., Basha, S. \& Jha, B. 2009. Kinetics equilibrium and thermodynamic studies on biosorption of hexavalent chromium by dead fungal biomass of marine Aspergillus niger. Chemical Engineering Journal, Vol: 145, No. 1, (January, 2009), 489495, ISSN 1385-8947.

Kirk, M.P., Cannon, F.P., David, C.J. \& Stalpers, A.J. 2001. Dictionary of the fungi, 51-52, 385387, (2001). CABI Publishing, UK.

Krishna, K.R., \& Philip, L. 2005. Bioremediation of Cr (VI) in contaminated soils. Journal of Hazardous Materials, Vol: 121, No. 1-3, (January, 2005), 109-117, ISSN 0304-3894.

Kumar, R., Bishnoi, N.R., Garima, A. \& Bishnoia, B. 2008. Biosorption of chromium (VI) from aqueous solution and electroplating wastewater using fungal biomass. Chemical Engineering Journal, Vol: 135, No. 3 (February, 2008), 202-208, ISSN 1385-8947.

Lee, K., Buckley, L. \& Campbell, C.C. 1975. An aminoacid liquid synthetic medium for the development of mycelial and yeast forms of Candida albicans. Journal of Medicine Veterinary and Mycology, Vol: 13, (February, 1975), 148-153, ISSN 0268-1218. 
Lee, D.C., Park, C.J., Yung, J.E. \& Jeong, Y.H. 2000. Screening of hexavalent chromium biosorbent from marine algae. Applied Microbiology and Biotechnology, Vol: 54, No. 3, (September, 2000), 445-448, ISSN 1432-0614.

Leyva-Ramos, R., Bernal-Jacome, L.A. \& Acosta-Rodriguez, I. 2005. Adsorption of cadmium (II) from aqueous solution on natural and oxidized corncob. Separation and Purification Technology, Vol: 45, No. 1 (September, 2005), 41-49, ISSN 1383-5866.

Liu, T., Li, H., Li, Z., Xiao, X., Chen, L. \& Deng, L. 2007. Removal of hexavalent chromium by fungal biomass of Mucor racemosus: influencing factors and removal mechanism. World Journal of Microbiology and Biotechnology, Vol: 23, No. 12, (December, 2007), 1685-1693, ISSN 0959-3993.

Lofroth, G. \& Ames, B.N. 1978. Mutagenicity of inorganic compounds in Salmonella typhimurium: Arsenic, chromium and selenium. Mutation Research, Vol: 53, No. 2, (September, 1978), 65-66, ISSN 1383-5742.

Marsh, T.L. \& McInerney, M.J. 2001. Relationship of hydrogen bioavailability to chromate reduction in aquifer sediments. Applied and Environmental Microbiology, Vol: 67, No. 4, (April, 2001), 1517-1521, ISSN 1098-5336.

Mattuschka, B. \& Straube, G. 1993. Biosorption of metals by waste biomass. Journal of Chemical Technology Biotechnology, Vol: 58, No. 1 (January, 1993), 57-63, ISSN 1097-4660.

Morales-Barrera, L. \& Cristiani-Urbina, E. 2008. Hexavalent Chromium Removal by a Trichoderma inhatum Fungal Strain Isolated from Tannery Effluent. Water Air Soil Pollution, Vol: 187, (April, 2001), 327-336, ISSN 1573-2932.

Muter O., Patmalnieks A. \& Rapoport A. 2001. Interrelations of the yeast Candida utilis: metal reduction and its distribution in the cell and medium. Process Biochemistry, Vol: 36, (April, 2001), 963-970, ISSN 0032-9592.

Nourbakhsh, M., Sag, Y., Ozer, D., Aksu, Z., Kutsal T.A. \& Caglar, A. 1994. A comparative study of various biosorbents for removal of chromium (VI) ions from industrial wastewater. Process Biochemistry, Vol: 29, No. 1, (January, 1994), 1-5, ISSN 0032-9592.

Pantaler, R.P. \& Pulyaeva, I.V. 1985. A spectrophotometric study of complexation between chromium and chromazurol S. Journal of Analytical Chemistry (Moscow), Vol: 40, (May, 1985), 1634-1639, ISSN 1061-9348.

Oliver, D.S., Brockman, F.J., Bowman, R.S., Thomas L. \& Kieft, T.L. 2003. Microbial reduction of hexavalent chromium under vadose zone conditions. Journal of Environmental Quality, Vol: 32, No. 1, (January, September, 2003), 317-324, ISSN 0047-2425.

Park, D., Yung, Y.S. \& Park, J.M. 2004. Reduction of Hexavalent chromium with the brown seaweed Ecklonia Biomass. Environmental Science Technology, Vol: 38, No. 18, (September, 2004), 4860-4864, ISSN 1735-2630.

Park, D., Yun, Y.S., Cho, H.Y. \& Park, J.M. 2004. Chromium biosorption by thermally treated biomass of the brown seaweed, Ecklonia sp. Industrial and Engineering Chemistry Research, Vol: 43, No. 26, (December, 2004), 8226-8232, ISSN 0888- 5885.

Pas, M., Milacic, R., Drasar, K., Pollack, N. \& Raspor, P. 2004. Uptake of chromium (III) and chromium (VI) compounds in the yeast cell. Biometals, Vol: 17, No. 1, (January, 2004), 25-33, ISSN 0966-0844.

Pepi M. \& Baldi F. 1992. Modulation of chromium (VI) toxicity by organic and inorganic sulfur species in yeasts from industrial Wastes. BioMetals, Vol: 5, No. 2, (April, 2004), 179-185, ISSN 0966-0844.

Prasenjit, B. \& Sumathi, S. 2005. Uptake of chromium by Aspergillus foetidus. Journal of Material Cycles and waste Management, Vol: 7, No. 2, (August, 2005), 88-92, ISSN 1438-4957. 
Puranik, P.R. \& Paknikar, K.M. 1999. Biosorption of lead, cadmium, and zinc by Citrobacter strain MCM B-181: characterization studies. Biotechnology Progress, Vol: 15, No. 2, (march-april 1999), 228-237, ISSN 1520-6033.

Ramírez-Ramírez, R., Calvo-Méndez, C., Avila-Rodríguez, M., Lappe, P., Ulloa, M., Vázquez-Juárez, R. \& Gutiérrez-Corona, J.F. 2004. Cr (VI) reduction in a Chromateresistant strain of Candida maltose isolated from the leather industry. Antonie van Leeuwenhoek, Vol: 85, No. 1, (January, 2004), 63-68, ISSN 0000020151.

Rodríguez, M.E., Miranda, R.C., Olivas, R. \& Sosa, C.A. 2008. Efectos de las condiciones de operación sobre la biosorción de $\mathrm{Pb}^{++}, \mathrm{Cd}^{++}$y $\mathrm{Cr}^{+++}$en solución por Saccharomyces cerevisiae residual. Información Tecnológica, Vol: 19, No. 6, (Noviembre-Diciembre, 2008), 47-55, ISSN 0716-87.

Sag, Y. \& Aktay, Y. 2002. Kinetic studies on sorption of Cr (VI) and Cu (II) ions by chitin, chitosan and Rhizopus arrhizus. Biochemical Engineering Journal, Vol: 12, No. 2, (March, 2002), 143-153, ISSN 1369-703X.

Sahin, Y. \& Öztürk, A. 2005. Biosorption of chromium (VI) ions from aqueous solution by the bacterium Bacillus thuriengensis. Process Biochemistry, Vol: 40, No. 5, (April, 2001), 1895-1901, ISSN 1359-5113.

Sandana Mala, J.G., Unni Nair, B. \& Puvanakrishnan, R. 2006. Bioaccumulation and biosorption of chromium by Aspergillus niger MTCC 2594, Journal of General and Applied Microbiology, Vol: 52, No. 3, (September, 2006), 179-186, ISSN 1349-8037.

Seng, H. \& Wang, Y.T. 1994. Biological reduction of chromium by E. coli. Journal of Environmental Engineering, Vol: 120, No. 4, (July, 1994), 560-572, ISSN 0733-9372.

Smith, W.A., Apel, W.A., Petersen, J.N. \& Peyton, B.M. 2002. Effect of carbon and energy source on bacterial chromate reduction. Bioremediation Journal, Vol: 6, No. 1, (March, 2002), 205-215, ISSN 1547-6529.

Srinath, T., Verma, T., Ramteke, P.W., \& Garg, S.K. 2002. Chromium (VI) biosorption and bioaccumulation by chromate resistant bacteria, Chemosphere, Vol: 48, No. 4, (July, 2002), 427-435, ISSN 0045-6535.

Srivastava, S. \& Thakur, I.S. 2007. Evaluation of biosorption potency of Acinetobacter sp. for removal of hexavalent chromium from tannery effluent. Biodegradation, Vol: 18, No. 5, (October, 2007), 637-646, ISSN 0923-9820.

Tewari, N., Vasudevan, P. \& Guha, B. 2005. Study on biosorption of Cr (VI) by Mucor hiemalis. Biochemical Engineering Journal, Vol: 23, No. 2, (April, 2005), 185-192, ISSN 1369-703X.

Tokunaga, T.K, Wan, J., Firestone, M.K., Hazen, T.C., Olson, K.R., Donald, J. Herman, D.J. Sutton, S.R. \& Lanzirotti, A. 2003. Bioremediation and Biodegradation. In situ reduction of chromium(VI) in heavily contaminated soils through organic carbon amendment. Journal of Environmental Quality, Vol: 32, No. 5, (September, 2003), 1641-1649, ISSN 0047-2425.

Ucun, H., Bayhan, Y.K., Kaya, Y., Cakici, A. \& Algur, O.F. 2002. Biosorption of chromium (VI) from aqueous solution by cone biomass of Pinus sylvestris. Bioresource Technology, Vol: 85, No. 2, (November, 2002), 155-158, ISSN 09608524.

Wong, P.T. \& Trevors, J.T. 1988. Chromium toxicity to algae and bacteria. In: Chromium in the Natural and Human Environments. Nriagu, J.O., Nieboer, E. Eds Wiley, New York, 305-315.

Zafar, S., Aqil, F. \& Ahmad, I. 2007. Metal tolerance and biosorption potential of filamentous fungi isolated from metal contaminated agricultural soil. Bioresource Technology, Vol: 98, No. 13, (September, 2007), 2557-2561, ISSN 09608524. 


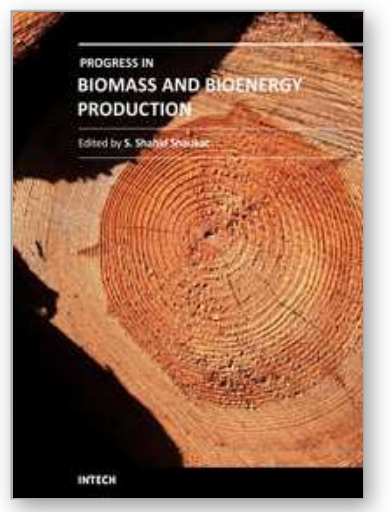

\author{
Progress in Biomass and Bioenergy Production \\ Edited by Dr. Shahid Shaukat
}

ISBN 978-953-307-491-7

Hard cover, 444 pages

Publisher InTech

Published online 27, July, 2011

Published in print edition July, 2011

Alternative energy sources have become a hot topic in recent years. The supply of fossil fuel, which provides about 95 percent of total energy demand today, will eventually run out in a few decades. By contrast, biomass and biofuel have the potential to become one of the major global primary energy source along with other alternate energy sources in the years to come. A wide variety of biomass conversion options with different performance characteristics exists. The goal of this book is to provide the readers with current state of art about biomass and bioenergy production and some other environmental technologies such as Wastewater treatment, Biosorption and Bio-economics. Organized around providing recent methodology, current state of modelling and techniques of parameter estimation in gasification process are presented at length. As such, this volume can be used by undergraduate and graduate students as a reference book and by the researchers and environmental engineers for reviewing the current state of knowledge on biomass and bioenergy production, biosorption and wastewater treatment.

\title{
How to reference
}

In order to correctly reference this scholarly work, feel free to copy and paste the following:

Juan Fernando Cárdenas and Ismael Acosta (2011). Hexavalent Chromium Removal by a Paecilomyces sp, Progress in Biomass and Bioenergy Production, Dr. Shahid Shaukat (Ed.), ISBN: 978-953-307-491-7, InTech, Available from: http://www.intechopen.com/books/progress-in-biomass-and-bioenergy-production/hexavalentchromium-removal-by-a-paecilomyces-sp

\section{INTECH}

open science | open minds

\section{InTech Europe}

University Campus STeP Ri

Slavka Krautzeka 83/A

51000 Rijeka, Croatia

Phone: +385 (51) 770447

Fax: +385 (51) 686166

www.intechopen.com

\section{InTech China}

Unit 405, Office Block, Hotel Equatorial Shanghai

No.65, Yan An Road (West), Shanghai, 200040, China

中国上海市延安西路65号上海国际贵都大饭店办公楼 405 单元

Phone: +86-21-62489820

Fax: $+86-21-62489821$ 
(C) 2011 The Author(s). Licensee IntechOpen. This chapter is distributed under the terms of the Creative Commons Attribution-NonCommercialShareAlike-3.0 License, which permits use, distribution and reproduction for non-commercial purposes, provided the original is properly cited and derivative works building on this content are distributed under the same license. 